\title{
MEMBANGUN SUBJEKTIVITAS PENONTON MELALUI PENDEKATAN INTERAKTIF PADA PENYUTRADARAAN FILM MOCKUMENTARY "BOOKING OUT"
}

\author{
Fuad Hilmi Hirnanda \\ Endang Mulyaningsih \\ Gregorius Arya Dhipayana \\ Jurusan Film \& Televisi, Fakultas Seni Media Rekam, Institut Seni Indonesia Yogyakarta \\ Jl. Parangtritis km. 6.5 Yogyakarta Telp. (0274) 381047
}

\begin{abstract}
ABSTRAK
Film mockumentary merupakan suatu bentuk film yang menyimulasikan gaya film dokumenter untuk menceritakan suatu bentuk naratif tertentu, maksud dari menyimulasikan yaitu bentuk film fiksi yang menggunakan teknik film dokumenter untuk mewujudkannya. Film jenis ini mampu menghadirkan suatu realita, fakta, argumentasi serta bentuk refleksi dari filmmaker melalui narasi dramatis yang dibangun. Subjektivitas penonton dibangun melalui persepsi mereka akan bentuk film ini. Film "Booking Out" mengangkat isu seksualitas di masyarakat Indonesia, khususnya prostitusi online yang semakin marak seiring dengan perkembangan teknologi. Melalui karakter Udin, diceritakan bagaimana seorang pelaku penipu berkedok prostitusi online menjalakan aksinya. Penciptaan karya film ini diwujudkan menggunakan pendekatan interaktif, ditunjung melalui akting impersonator, casting by type, penggunaan tata kamera dynamic shot dan subjective shot. Konsep ini akan membentuk konstruksi dokumenter yang dapat memberikan kedekatannya dengan penonton. Penonton akan dibawa melalui dokumentasi kehidupan Udin dan keluarganya agar ikut merasakan interaksi terhadap tokoh-tokoh pada film hingga momen-momen kejadian yang terekam pada kamera.
\end{abstract}

Kata kunci: Penyutradaraan, Film Mockumentary, Pendekatan Interaktif, Subjektivitas

\section{PENDAHULUAN}

Film "Booking Out" merupakan film mockumentary tentang kehidupan seorang penipu yang menawarkan jasa prostitusi online palsu. Film ini dilihat dari sudut pandang pembuat film yang sedang mengikuti kegiatan sehari-hari seseorang yang bernama Udin dan menjadikannya sebagai film dokumenter pendek. Film mockumentary masih termasuk dalam bentuk film fiksi, namun menggunakan teknik atau gaya dalam film dokumenter dan biasa dikenal sebagai film yang dibuat menggunakan teknik found footages atau temuan beberapa potongan gambar kemudian dibentuk kedalam sebuah struktur penceritaan tertentu. Seperti halnya di film ini, found footages dilihat melalui dokumentasi kehidupan Udin yang dibentuk menjadi sebuah film dokumenter oleh seorang tokoh pembuat film dokumenter. Film dokumenter diidentifikasi dengan film non-fiksi yang membangun dirinya melalui kisah nyata, dan bertujuan untuk mengungkapkan apa yang sebenarnya terjadi dalam dunia subjeknya. Sedangkan, dalam bentuk film fiksi akan mengkonstruksikan dirinya pada dunia imajiner, mengambil subjeknya dari peristiwa nyata, dan jelas film fiksi dikonstruksi berdasarkan suatu 


\section{Luluk Ulhasanah}

Pemaknaan Stereotip Gender Dan Kelas Sosial Pada Film Little Women

skenario/naskah. Film mockumentary memiliki hubungan yang kompleks antara film dokumenter dan film fiksi. Film mockumentary dalam dunia fiksi mewakili dunia imajinernya yang dibangun berdasarkan naskah, sedangkan dalam dunia dokumenter bentuknya menghasilkan klaim yang mewakili dunia nyata. Hal tersebut disebabkan karena apa yang nampak di depan kamera akan terlihat sangat nyata. Secara garis besar film ini mengangkat isu seksualitas di masyarakat Indonesia, khususnya kota Yogyakarta. Seiring berkembangnya teknologi, pekerja seks komersial yang dahulu mencari pelanggan dengan menjajakan diri di pinggir jalanan bahkan ke remang-remang, kini perlahan beralih ke ranah online. Tentu dari perkembangan teknologi ini akan berdampak negatif ke generasi sekarang. Naskah "Booking Out" membangun perspektif terhadap isu seksualitas dengan kemasan film mockumentary. Persoalan seks online tentu akan lebih mudah disampaikan dengan satire, tanpa kita memberikan pelajaranpelajaran secara gamblang bahwa tindakan ini dilarang. Pembuat film dokumenter memiliki gaya dan pendekatan yang berbeda. Seperti Nichols yang mengemukakan bahwa tidak ada gaya tunggal dalam film dokumenter, tetapi ada berbagai jenis gaya, dan masing-masing gaya memiliki kualitas dan hubungan yang berbeda dengan audiensnya (Nichols, 2001). Dalam buku ini,
Nichols memperkenalkan enam mode utama film dokumenter yakni, the poetic mode, the expository mode, the observational mode, the participatory mode, the reflexive mode, dan the performative mode. Keenam mode ini membentuk subgenre dari film dokumenter dan juga menggambarkan berbagai bentuk dan pendekatan yang berbeda dari film dokumenter. Mode-mode ini juga penting untuk memahami film mockumentary, karena film mockumentary menggunakan beberapa mode yang populer dari film dokumenter seperti, expository mode, observational mode, dan participatory mode. Roscoe dan Hight juga menyatakan bahwa ada tiga utama mode dokumenter yang bisa digunakan dalam film mockumentary. Dalam hal ini ada mode observational yang mengacu pada directcinema dan cinéma vérité, mode ekspository, juga mode yang paling sering digunakan dalam mockumentary yaitu interaktif atau participatory yang menghadirkan langsung interaksi pembuat film. (Roscoe \& Hight, 2001).

Film mockumentary "Booking Out" menggunakan pendekatan interaktif, di mana pembuat film merupakan bagian dari aksi yang menjalankan cerita dan memposisikan dirinya sebagai partisipan yang ikut merasakan pengalaman yang dirasakan oleh subjeknya. Pada film ini, pembuat film dihadirkan dengan tokoh bernama Adi yang membuat film dokumenter tentang Udin, seseorang yang menjual jasa prostitusi online 
palsu. Bentuk interaktif terlihat dari dialog yang dilontarkan, aksi reaksi tokoh yang melihat ke arah kamera, dan beberapa bentuk tekstual yang memberikan informasi terhadap penonton. Pendekatan interaktif dalam film mockumentary menjadi teknik yang tepat digunakan agar penonton dapat merasakan secara langsung kedekatannya dengan film ini. Kamera mampu merekam dan mengikuti seluruh kegiatan subjek seakan-akan penonton hadir sebagai kamera tersebut. Selain itu, Interaksi tokoh yang melihat ke arah kamera dapat mengajak penonton berdialog. Bentuk ini untuk membangun subjektivitas penonton, karena penonton secara langsung dapat menyadari dirinya masuk atau terlibat ke dalam film. Persepsi penonton dalam menonton film dengan pendekatan interaktif dapat membuatnya merasakan film yang sedang ditonton merupakan film dokumenter. Membangun subjektivitas penonton juga dilakukan melalui penerapan tata artistik yang mendukung jalannya cerita dan pemilihan pemain yang dapat memerankan sesuai karakter. Selain itu, dengan penataan sinematografi yang menggunakan dynamic shot dan subjective shot, membuat logika seorang tokoh pembuat film yang sedang membuat film dokumenter. Meskipun film mockumentary berada dalam kategori film fiksi, namun kekuatannya berada dalam struktur bertutur yang menyerupai film dokumenter. Sudut pandang penonton dapat berasal dari pengalaman menonton yang sangat pribadi, harapannya penonton dapat merasakan kedekatannya terhadap film ini sehingga dapat menemukan pengalaman menonton yang baru.

\section{Dalam penciptaan film "Booking} Out" pembangunan subjektivitas memerlukan beberapa elemen teknis yaitu mise en scene, karena unsur sinematik ini adalah unsur yang paling mudah kita kenali melalui gambar yang terlihat di layar, yaitu latar cerita, tata rias, kostum, pencahayaan, dan pergerakan adegan. Konsep mise en scene di film "Booking Out" terlihat di mana latar tempat Udin yang tinggal di suatu permukiman padat penduduk di kota Yogyakarta. Rumah Udin terdapat sebuah etalase yang berisi voucher pulsa dan kartu sim yang dia gunakan sebagai modal untuk menjadi pekerja seks online palsu. Beberapa artistik di kamarnya yang juga menunjang akan memperjelas bahwa dia bekerja sebagai pekerja seks online palsu. Sudut pandang terhadap karakter Udin sebagai pekerja seks online palsu yaitu permasalahan yang dihadapinya bukan hanya masalah ekonomi, melainkan akibat perkembangan teknologi yang akhirnya membuat dia melakukan pekerjaan itu karena kemudahannya dalam mendapatkan uang.

\section{OBJEK PENCIPTAAN}

\section{Prostitusi Online di Indonesia}

Pada saat ini perkembangan teknologi sudah sangat pesat, dengan berjalannya 


\section{Luluk Ulhasanah}

Pemaknaan Stereotip Gender Dan Kelas Sosial Pada Film Little Women

perkembangan tersebut membuat kehidupan manusia menjadi berubah dalam banyak bidang seperti, cara bergaul, gaya hidup maupun dalam berbusana. Perubahan tersebut membawa ke sisi positif dan negatif di dalam kehidupan masyarakat, bahkan ada yang kemudian membuat masyarakat resah dan khawatir karenanya. Salah satu masalah tersebut adalah penyakit sosial, dan di antara masalah sosial yang banyak terjadi di masyarakat Indonesia adalah prostitusi. Masyarakat biasanya mengetahui bahwa prostitusi dilakukan di sebuah daerah atau tempat, baik itu di pinggir jalan, pinggir rel, lokalisasi ataupun tempat lainnya dengan cara pelaku yang secara gamblang menjajakan dirinya dan menunggu pelanggan pengguna jasanya datang. Dengan adanya perkembangan teknologi serta pengaruh globalisasi, cara-cara yang dilakukan dalam bertransaksi sudah bermacam-macam. Tidak lagi dengan saling bertemu di tempat-tempat yang biasa menjajakan diri, mereka menggunakan media internet sebagai perantaranya.

Internet di Indonesia memang bukan sesuatu yang baru, namun pertumbuhannya pesat baru di sekitar tahun 2000-an. Semakin hari pengguna internet di Indonesia semakin bertambah jumlahnya, begitu pula dengan tarifnya yang semakin murah, merambah dari kota hingga ke pelosok-pelosok desa dan dapat diakses dari macam media. Beberapa macam media sosial yang biasa digunakan oleh pekerja prostitusi untuk melakukan pekerjaannya yaitu, Twitter, Facebook, dan Forum Kaskus. Selain media sosial, para pekerja prostitusi juga merambah sarana aplikasi percakapan, seperti Beetalk, MiChat, WeChat, dan Tinder.

Seperti halnya praktik prostitusi yang biasa dilakukan di pinggir-pinggir jalan, prostitusi online pun mempunyai mata rantai siapa saja yang terlibat dalam praktik prostitusi ini, baik yang secara langsung ikut di dalamnya dan yang tidak. Pekerja seks komersial inilah yang menjadi objek eksploitasi utama dari mata rantai praktik prostitusi. Pekerja seks komersial dalam dunia online ada macamnya, ada yang menggunakan pihak lain dalam hal managerial terkait beberapa kebutuhan, atau yang biasa disebut dengan muncikari, serta ada yang berjalan sendiri tanpa muncikari. Mata rantai utama dalam praktik ini sendiri adalah pihak penyewa jasa tersebut. Pihak penyewa inilah yang menjadi titik penentu bagaimana transaksi prostitusi online ini bisa terus berlangsung. Selain dari beberapa pihak yang telah dijelaskan sebelumnya, ada juga pihak-pihak yang secara tidak langsung mendukung adanya praktik asusila ini, yaitu orang-orang yang memanfaatkan keuntungan dari praktik prostitusi online. Kegiatan penipuan bermodus prostitusi online semakin merambah. Mereka memanfaatkan mediamedia sosial untuk menjual jasa prostitusi palsu. Hubungan yang terjadi antara penyewa 
jasa dengan penipu ini biasanya melalui kesepakatan awal, yaitu dengan membayar uang muka terlebih dahulu untuk melakukan praktik asusila ini, namun setelah itu pihak penyewa tidak mendapatkan sesuai perjanjian di awal. Penipu membawa uang muka dan melalukan pemblokiran terhadap media sosial si penyewa jasa. Tindakan seperti ini merupakan salah satu efek negatif dari perkembangan teknologi khususnya internet di Indonesia.

\section{Kekerasan Seksual Pada Perempuan}

Pelecehan seksual adalah terminologi yang paling tepat untuk memahami pengertian kekerasan seksual. Pelecehan seksual memiliki rentang yang sangat luas, mulai dari ungkapan verbal (komentar, gurauan dan sebagainya) yang jorok/tidak senonoh, perilaku tidak senonoh (mencolek, meraba, mengendus, memeluk dan sebagainya), mempertunjukkan gambar porno/jorok, serangan dan paksaan yang tidak senonoh seperti, memaksa untuk mencium atau memeluk, mengancam akan menyulitkan si perempuan bila menolak memberikan pelayanan seksual, hingga perkosaan.

Pelecehan seksual karena rentangnya yang demikian luas, dapat terjadi dimanapun selama ada percampuran lelaki dan perempuan ataupun di komunitas yang homogen. Pelecehan seksual banyak terjadi di tempat kerja maupun luar tempat kerja atau di tempat-tempat umum, dan bahkan sangat umum ditemukan bahwa pelakunya adalah orang yang tidak dikenal oleh korban, seperti misalnya pelecehan seksual di dalam bus umum, di jalanan, di pasar dan sebagainya. Pelaku kejahatan kesusilaan dan pelecehan seksual bukan dominasi mereka yang berasal dari golongan ekonomi menengah atau rendah apalagi kurang atau tidak berpendidikan sama sekali, melainkan pelakunya sudah menembus semua strata sosial dari strata terendah sampai tertinggi.

Kekerasan seksual perlu diperhatikan karena berperan penting dalam kehidupan perempuan. Agar perempuan mempunyai hak secara martabat dalam menjalani kehidupannya. Penghapusan kekerasan seksual adalah segala upaya untuk mencegah terjadinya kekerasan seksual, melindungi dan mengupayakan tidak terjadi kekerasan seksual secara berulang-ulang. Melihat jumlah kekerasan yang semakin mengkhawatirkan di kalangan masyarakat, undang-undang ini menjadi sebuah upaya mendekatkan akses keadilan bagi korban, yang menjamin masyarakat bebas dari kekerasan seksual. Sebaiknya undangundang ini segera disahkan agar tidak semakin banyak yang menjadi korban dalam kekerasan seksual. Hal ini sangat penting untuk ditegaskan karena kasus kekerasan semakin hari kian meningkat.

Pengaturan dalam Kitab UndangUndang Hukum Pidana (KUHP) tentang kekerasan seksual sangat terbatas. Secara 


\section{Luluk Ulhasanah}

Pemaknaan Stereotip Gender Dan Kelas Sosial Pada Film Little Women

garis besar, bentuk kekerasan seksual hanya perkosaan dan pencabulan. Pengaturan yang tersedia itupun belum sepenuhnya menjamin perlindungan hak korban. Rancangan Undang-Undang Penghapusan Kekerasan Seksual (RUU PKS) mengatur tindak pidana kekerasan seksual yang tidak seluruhnya diatur dalam Kitab Undang-Undang Hukum Pidana (KUHP).

$$
\text { Rancangan Undang-Undang }
$$

Penghapusan Kekerasan Seksual (RUU PKS) bertujuan untuk melindungi hak-hak korban yang selama ini tidak dipedulikan. Penting bagi masyarakat, terutama perempuan untuk mengetahui pengesahan RUU PKS ini. "Dari data pada tahun 2012-2013, komnas perempuan mencatat bahwa setiap dua jam, terdapat tiga perempuan yang mengalami kekerasan seksual di Indonesia", semua butuh pendekatan hukum. Jika tidak ada pendekatan hukum, maka akan terus membiarkan korban tanpa pemulihan dan pelaku melenggang tanpa adanya tindak hukum. Ini sangat penting untuk perubahan pola pikir serta sikap dan mencegah untuk perbuatan yang sama terulang di masa depan. Pada akhirnya RUU PKS ini bukan hanya penting bagi keadilan dan kesejahteraan bangsa Indonesia, tetapi juga perlu dikawal oleh berbagai Lembaga dan didukung oleh masyarakat.

\section{KONSEP KARYA}

Film ini terinspirasi dari kehidupan nyata, sehingga melalui interaksi yang dilakukan secara langsung dengan subjek dan memperoleh seluruh informasi baik permasalahan atau kejadian yang subjek alami merupakan titik penting dalam penceritaanya. Hal itu kemudian membentuk suatu konsep besar film mockumentary dengan menggunakan pendekatan interaktif. Dalam pendekatan interaktif, pembuat film merupakan bagian dari aksi yang menjalankan cerita. Pertanyaan dan komentar yang dilontarkan merupakan hal yang penting dalam pendekatan interaktif. Subjek dalam film tersebut bisa menyampaikan pendapat dan pandangan mereka terhadap permasalahan yang diangkat oleh pembuat filmnya. Pendekatan interaktif menjadi sangat efektif untuk mengarahkan subjek didalam film, agar sesuai keinginan sutradara dalam mengarahkan jalan cerita.

Dalam perkembangannya, pendekatan dokumenter menjadi tren dalam film fiksi hingga kini. Penyajian dan kemasan filmnya persis layaknya film dokumenter, tetapi kisahnya hanya rekaan belaka. Begitu meyakinkan pendekatan gaya dokumenter yang digunakan membuat penonton sering kali menganggap bahwa film yang mereka tonton ini benar-benar terjadi (Pratista, 2017:33).

Roscoe dan Hight (2001:18-20) dalam bukunya yang berjudul Faking It: Mock Documentary and the subversion of factuality, menyatakan ada beberapa tingkatan film mockumentary yaitu Parody, 
Critique, dan Deconstruction. Film "Booking Out" menggunakan konsep film mockumentary pada tingkat deconstruction, di mana pada kategori ini akan menggunakan aktor yang kurang dikenal atau aktor yang tidak pernah memerankan karakter utama, strategi pemasaran alternatif, dan menggunakan estetika dokumenter sebagai fondasi film. Keterlibatan antara karakter dengan kamera secara aktif pada proses bercerita menjadikan persepsi yang bervariasi di antara penonton, sehingga pendekatan interaktif merupakan metode yang cocok dalam pembangunan persepsi penonton atau subjektivitas penonton dalam melihat film ini. Konstruksi film ini akan dibangun melalui konstruksi dokumenter, namun secara konsep penyutradaraan, sinematografi, tata artistik, tata lampu, tata suara, editing, tata busana, dan tata rias, sudah dirancang dari awal seperti film fiksi pada umumnya.

Satu faktor penting untuk membangun interaktif dalam film mockumentary ini, adalah dengan cara membangun dialog antara pemain dan sutradara yang pastinya akan menggerakkan cerita. Bentuk interaktif dalam film ini yaitu antara tokoh Filmmaker, Udin, Arum, Tole, dan beberapa pemain yang terlihat pada konstruksi dokumenter. Aksi reaksi tokoh terhadap kamera sangat penting untuk membangun konstruksi subjektivitas penonton. Interaksi juga terlihat antara Udin dengan Arum dan Tole yang menyadari adanya kamera yang sedang merekam mereka. Reaksi Arum dan Tole terhadap kamera berguna untuk memperkuat konstruksi dokumenter. Unsur yang tidak lepas dari konsep penyutradaraan film mockumentary "Booking Out" adalah proses pengadeganan pemain. Dalam pengadeganan yang akan dibangun di film ini yaitu aktor menggunakan pendekatan impersonator, karena beberapa aktor di film ini harus ditekankan melalui bakatnya lalu melepaskan identitas diri dan kepribadiannya untuk mengambil alih secara penuh seluruh kepribadian dan watak tokoh yang sudah dibuat. Akting pemain terlihat natural, agar penonton percaya bahwa yang mereka tonton merupakan subjek nyata. Dalam hal ini, aktor harus mengetahui sangat detail fisik tokoh, perasaan, dan kehidupannya untuk mengenali lebih dalam tokoh yang dimainkan, sehingga memberikan perasaan nyata tokoh tersebut kepada penonton. Dalam sequence fiksi, penonton sadar bahwa realitas sesungguhnya dalam film ini berada pada akhir film. Proses casting film ini akan menggunakan casting by type dan casting by ability. Casting by type dan ability dimaksudkan untuk memilih karakter berdasarkan fisik, sosiologis, psikologis yang sesuai pada 3 dimensi tokoh film dan kemampuan aktor dalam memainkan suatu karakter yang sudah diciptakan.

Sinematografi pada film "Booking Out" akan menggunakan dynamic shot yang 


\section{Luluk Ulhasanah}

Pemaknaan Stereotip Gender Dan Kelas Sosial Pada Film Little Women

bertujuan membangun realitas karena mendekatkan dengan situasi sebenarnya yang dialami tokoh dalam cerita ini melalui kamera. Dynamic shot pada film ini juga berguna untuk membangun teknik-teknik penggunaan kamera pada film dokumenter. Bentuk subjektivitas terlihat dalam cara pembuat film menerapkan kamera hadir sebagai pembuat film, yang dalam pengambilan gambarnya kamera akan menempatkan subjek layaknya seperti manusia biasa yang berkegiatan sehari-hari. Dynamic shot akan diterapkan dengan beberapa unsur yaitu pergerakan kamera, komposisi, ukuran gambar, dan sudut pengambilan gambar tersebut yang akan menghasilkan gambar yang memiliki kekuatan untuk meningkatkan emosional dalam adegan untuk mengikuti karakter serta pergerakan kamera. Penataan cahaya pada film "Booking Out" akan menggunakan konsep available light di mana sumber pencahayaan merupakan hasil dari matahari, dan artificial light yang merupakan pencahayaan buatan yang terdapat pada benda-benda pembantu, yang menimbulkan/menciptakan cahaya tambahan. Kedua konsep tersebut berguna untuk menunjukkan keadaan cahaya yang sesungguhnya pada setiap lokasi sehingga penonton menjadi sadar bahwa apa yg ada di layar adalah cahaya yg sebenarnya. Di beberapa scene film ini, akan menggunakan arah pencahayaan frontal lighting, yaitu arah pencahayaan yang berfungsi menegaskan bentuk sebuah objek atau wajah karakter. Penataan artistik dalam film mockumentary "Booking Out" bukan hanya difungsikan sebagai bagian estetis, namun juga digunakan untuk memperkuat setting sebagai latar belakang tokoh. Setting atau tempat tinggal Udin digambarkan pada lingkungan yang padat penduduk. Udin tinggal di bantaran sungai Code kota Yogyakarta, di rumahnya Udin menjual pulsa dan kartu sim yang sekaligus dia jadikan sebagai modal dalam penipuan prostitusi online yang dia lakukan.

$$
\text { Teknik editing mampu }
$$

mempengaruhi naratif dalam memanipulasi waktu. Konsep film "Booking Out" akan menggunakan editing diskontinuiti, dengan menggunakan teknik jump cut. Jump cut merupakan sebuah lompatan gambar dalam satu rangkaian shot akibat perubahan posisi karakter atau objek dalam latar yang sama, atau bisa sebaliknya, posisi karakter dan objek tetap, namun latar berubah seketika. Efeknya akan tampak seperti seorang karakter atau objek berpindah posisi atau berpindah lokasi secara mendadak. (Pratista, 2017: 192). Pada film "Booking Out", teknik jump cut berguna untuk mementingkan sebuah moment dalam konstruksi film dokumenter. Dalam segi teknik ini akan memperlihatkan sebab-akibat cerita melalui moment yang dirangkai hingga menjadi suatu cerita, walaupun akan melanggar aturan 
kontinuitas ruang, temporal, serta grafik secara sistematik.

\section{PEMBAHASAN}

Penyutradaraan dalam sebuah film tak lepas dari visi besar sutradaranya. Visi besar ini yang nantinya akan terlihat pada karya filmnya. Pada film "Booking Out" visi besar penyutradaraan adalah menampilkan konstruksi dokumenter. Unsur yang tak lepas dari penyutradaraan film ini adalah proses pengadeganan pemain. Pendekatan yang digunakan dalam pengadeganan pemain yaitu pendekatan impersonator. Pendekatan ini perlu ditunjang melalui referensi adegan, sifat manusia, foto, musik, dan kebiasaankebiasaan tokoh. Tokoh Udin, dimainkan oleh seorang aktor bernama Alex Suhendra. Sutradara memberikan beberapa referensireferensi adegan film dokumenter, salah satunya film "Tole (Children on The Street)"

Pada dasarnya akting dalam film ini, pemain berusaha untuk bermain secara natural. Penekanan natural yang dimaksud dalam film ini adalah, pemain bermain layaknya seseorang aktor yang sedang tidak beradegan. Mereka dapat menyadari bahwa ada kamera yang sedang merekam mereka. Mereka dapat menatap kamera lalu berinteraksi dengannya. Maka dari aksi reaksi antara pemain dengan kamera membuat penonton menyadari bahwa yang mereka tonton merupakan konstruksi dokumenter.

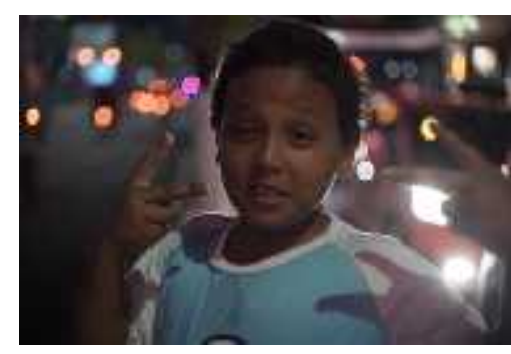

Gambar 1 Still photo film Tole "Children on the street"

Pada konsep sinematografi, film ini menggunakan dynamic shot dan subjective shot. Unsur-unsur yang diterapkan dalam dynamic shot yaitu, pergerakan kamera, komposisi, ukuran gambar, dan sudut pengambilan gambar. Subjective shot diterapkan karena dalam pengambilan gambarnya bersumber pada subjek tokoh Adi. Kamera berperan sebagai Adi yang sedang mengikuti kegiatan-kegiatan Udin dan keluarganya. Dengan subjective shot penonton juga mendapatkan pengamalan menonton yang lebih karena penonton akan merasa lebih dekat dengan tokoh-tokoh yang ada di dalam film.

Subjektif shot bertindak sebagai mata penonton. Setiap penonton akan menerima kesan bahwa dia di tempat kejadian dalam film, ia tidak hanya melihat peristiwa dan mengamati, namun ia menyelami dari setiap peristiwa dalam film. Subjektif shot sangat membantu dalam memperkuat sisi dramatik dalam penuturan cerita. 


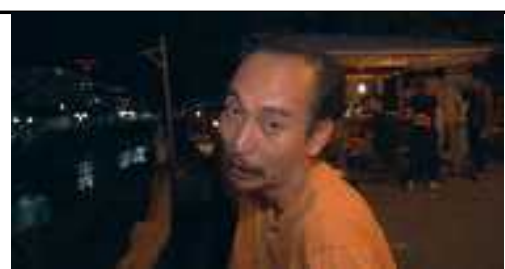

Gambar 2 Contoh subjective shot.

Sudut pengambilan gambar pada film ini akan selalu mengikuti pergerakan pemain, sudut kamera secara logika bersumber dari seseorang yang sedang merekam dan mengikuti kehidupan Udin. Tidak ada dekupase shot, semua shot bersumber pada sudut kamera yang sama, hanya saja beberapa shot perlu diambil untuk kegunaan insert pada editing. Blocking pada pemain sudah dipikirkan sejak reherseal, sehingga dapat memudahkan penata kamera dalam mengikuti pemain. Wawancara menjadi sangat penting, karena informasi yang dihasilkan dari wawancara dapat memuat argumentasi yang penting untuk menjalankan cerita. Pada pendekatan interaktif, pembuat film merupakan bagian dari aksi yang menjalankan cerita. Bentuk pertanyaan dan komentar yang dilontarkan bertujuan untuk argumentasi pembuat film terhadap permasalahan yang sedang diangkat dan sama sekali tidak ada usaha untuk menjadi netral terhadap permasalah tersebut. Pada scene 15, Arum terlihat sangat kesal karena perlakuan Udin terhadap dia. Dia menceritakan bahwa hal yang Udin lakukan ke Arum, tidak bisa terus-menerus untuk dibiarkan. Ada dialog penting dari Arum yang muncul dari scene ini yaitu, "masa iya mas, aku harus bikin twitter do your magic, biar masku kapok?”. Kalimat Arum menjadi penting karena pada akhirnya nanti Arum akan benar-benar membuat twitter do your magic, yang diperlihatkan pada akhir film. Secara struktur, scene 15 akan dibenturkan dengan statement Udin pada scene 16. Udin berusaha untuk membantah kata-kata Arum. Udin merasa jika pekerjaan yang dilakukannya merupakan pekerjaan yang tidak salah baginya. Perasaan denial ini yang ditunjukkan agar penonton merasa bahwa Udin berseberangan dengan tokoh Arum.

Tata busana film ini sudah dirancang sesuai color palette pada setiap tokoh, Udin lebih condong memiliki warna hangat karena untuk memperkuat karakternya. Pergerakan warna pada tokoh Udin dapat terealisasikan dengan baik, mulai dari scene 2-5 menggunakan kaus warna merah marun, scene 6-7 kaus warna merah, scene 9-11 kaus warna oranye, scene 13-14 warna oranye, scene 16 kaus warna abu-abu, dan scene 1720 kaus warna krem. Pergerakan warna pada tokoh Arum berlawanan dengan tokoh Udin, dimulai dari warna putih, pink, dan diakhiri dengan warna merah marun. Warna ini menunjukkan karakter Arum secara tangga dramatik, pada awal film menunjukkan tidak adanya masalah antara Arum dengan Udin, hingga akhirnya warna merah marun menunjukkan permasalahannya dengan Udin. Selain itu, warna merah marun pada tokoh Arum untuk menunjukkan sisi berani 
dalam dirinya untuk bertindak setelah merasa dirinya telah dilecehkan oleh Udin. Sedangkan pada karakter Tole mempunyai perbedaan dari konsep awal, yang semula warna tokoh Tole menggunakan warnawarna dingin. Realisasi dari tata busana tokoh Tole menggunakan warna-warna gelap karena untuk menunjukkan peran Tole sebagai anak yang netral dengan kondisi keluarga seperti itu. Jadi pergerakan warna dilakukan pada dua karakter, yaitu Udin dan Arum. Pembangunan karakter Udin juga diperlihatkan melalui penataan artistik. Udin sebagai penjual pulsa rumahan maka perlu membangun set konter pada lokasi rumah. Poster-poster perempuan seksi pada dinding kamar Udin juga menunjukkan karakter Udin yang tergila-gila dengan perempuanperempuan seksi. Untuk memperkuat karakter Udin yang mempunyai gimmick dari hewan tikus, sutradara memberikan poster tikus pada kamar Udin sebagai simbol representasi karakter Udin yang seperti tikus.

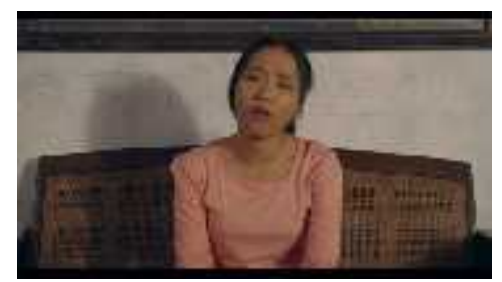

Gambar 3 Wawancara Arum pada scene 15.

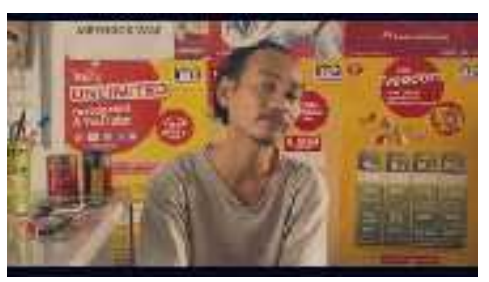

Gambar 4 Wawancara Udin pada scene 16

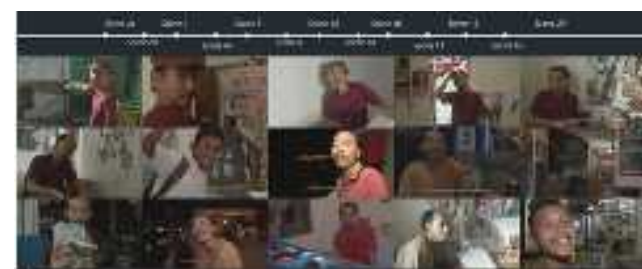

Gambar 5 Capture scene interaksi tokoh.

Pada film "Booking Out" ada 13 titik yang memperlihatkan keterlibatan tokoh yang melihat ke kamera secara langsung. Pembangunan konstruksi dokumenter malalui pendekatan interaktif ini juga cenderung menekankan dialog aktor dan berinteraksi dengan kamera/pembuat film. Bentuk interaksi yaitu, adanya dialog antara pembuat film dengan tokoh yang ada di dalam film. Subjek dalam film tersebut bisa menyampaikan pendapat dan pandangan mereka terhadap permasalahan yang diangkat oleh pembuat filmnya. Sutradara akan menjadi benang alur dalam film ini dan berfungsi layaknya fungsi sensorik manusia, yaitu: melihat, mendengar, berbicara dan memberi respons. Sutradara tidak hanya melihat dan mendengar, namun sutradara akan memberi respons terhadap apaupun yang dialami oleh subjek

Banyak bentuk-bentuk penceritaan dalam film dokumenter, seiring berkembangnya zaman, muncul gaya bertutur yang semakin baru dari setiap pembuatnya. Bentuk tekstual dalam mengawali film dapat memberikan informasi lebih kepada penonton. Informasi pada awal film menjadi hal penting, karena akan mengetahui film apa yang akan ditonton 


\section{Luluk Ulhasanah}

Pemaknaan Stereotip Gender Dan Kelas Sosial Pada Film Little Women

nantinya, informasi seperti apa yang disuguhkan, hingga sebagai kedekatan antara filmmaker dengan penontonnya. Kedekatan informasi ini karena filmmaker memberikan bentuk tekstual secara langsung yang seakanakan mengajak berbicara kepada penontonnya. Bentuk ini merupakan salah satu bentuk interaksi filmmaker kepada penonton. Text awal pada film ini sebagai awal film dokumenter tentang Udin akan dimulai. "Seluruh footages dalam film ini sudah mendapat persetujuan dari pihak-pihak terkait". Kalimat tersebut menandakan bahwa ada kegiatan perekaman dengan hasil yang disebut sebagai footages, kemudian kata persetujuan akan menggiring penonton berfikir bahwa akan terjadi sesuatu hal karena filmmaker menuliskan kata persetujuan pada teks tersebut. Dikuatkan lagi dari kata "pihak-pihak terkait", yang menunjukkan proses perizinan filmmaker terhadap pihak-pihak terkait yang nanti akan terceritakan melalui film.

Pada text akhir, merupakan informasi terbaru mengenai Udin setelah adanya scene penangkapan. Bentuk tekstual akhir ini juga mengakhiri persepsi penonton tentang konstruksi dokumenternya, apakah mereka percaya film ini merupakan film dokumenter, ataupun fiksi. Informasi yang diberikan yaitu tentang hukuman yang dijatuhkan pada Udin setelah melakukan tindak kejahatan yang sepanjang film terekam. Dengan adanya kalimat "Setelah melalui serangkaian proses pemeriksaan di pengadilan", menunjukkan bahwa Udin sudah dijatuhi pidana dan sudah melewati masa sidang di pengadilan. Setelah riset panjang mengenai hukuman apa yang diterima untuk kasus Udin, maka hukum yang didapat yaitu, tindak penipuan dan pencemaran nama baik. Pencemaran nama baik dijelaskan pada UU ITE pasal 27 ayat (3), karena Udin telah menggunakan foto orang-orang tanpa izin.

Satu hal yang ingin digaris bawahi dalam film ini adalah persoalan pelecehan seksual terhadap perempuan dalam lingkup keluarga. Namun setelah banyak berbincang dengan teman-teman dari lintas jurusan, Arum belum bisa dikategorikan sebagai korban dalam pelecehan seksual yang terlihat dalam film. Maka dari itu film ini menjadi urgensi untuk segera mengesahkan rancangan undang-undang penghapusan kekerasan seksual. Agar korban-korban seperti Arum tidak semakin banyak dan dapat ditangani secara hukum.

Thread twitter do your magic milik Arum ditampilkan setelah adanya text akhir yang menjelaskan keadaan terkini tentang Udin. Hal ini semakin mengaburkan, apakah sepanjang film yang ditonton tadi merupakan film dokumenter atau fiksi. Subjektivitas penonton semakin dibangun melalui grafis twitter ini. Interpretasi penonton akan berbeda-beda, apakah Arum membuat thread sebelum ditangkapnya Udin, atau membuat thread setelah Udin ditangkap. Persoalan ini 
akan semakin jauh untuk menebak apakah orang-orang zaman sekarang gampang digerakkan dengan suatu hal yang sedang viral, ataukah orang-orang zaman sekarang harus bergerak ketika suatu hal tersebut sudah terlanjut viral. Sesungguhnya sebuah tragedi terjadi karena beberapa orang tidak berani untuk berbicara lantang dan melawan. Bentuk ini yang diberikan pada karakter Arum agar semua perempuan-perempuan yang mendapatkan pelecehan seksual agar speak up.

\section{KESIMPULAN}

Film mockumentary "Booking Out" merupakan film yang dihadirkan kepada penonton untuk melihat bagaimana realitas kehidupan seorang penipu prostitusi online menjalani hidup dengan keluarganya. Film mockumentary menyajikan bentuk fiksi dengan menggunakan teknik dokumenter yang menawarkan narasi dramatis melalui bentuk argumentasi pembuat filmnya.

Pendekatan interaktif menjadi sangat penting karena dengan pendekatan ini, sutradara memposisikan dirinya sebagai partisipan yang ikut merasakan pengalaman yang dirasakan oleh subjek, di mana subjek dalam film ini yaitu, Udin seorang penipu prostitusi online palsu. Keterlibatan antara tokoh dengan kamera secara aktif dalam proses bercerita memberikan persepsi yang bervariasi kepada para penonton. Maka dari itu, pengadeganan yang diarahkan sutradara kepada pemain sangat penting, agar membuat karakter tokoh lebih muncul dan membuatnya lebih natural.

Pada film "Booking Out", pembangunan subjektivitas penonton berhasil divisualisasikan karena adanya kematangan pada konsep pendekatan interaktif. Penonton dapat merasakan kedekatannya dengan tokoh-tokoh di dalam film karena secara langsung mereka dibawa melalui konstruksi dokumenter yang dibangun melalui pendekatan interaktif. Film mockumentary berada dalam kategori film fiksi, namun memiliki kekuatan pada struktur bertutur yang menyerupai film dokumenter karena menggunakan teknik pendekatan interaktif. Konstruksi dokumenter melalui pendekatan interaktif berfungsi sebagai pembangun subjektivitas penonton dalam melihat film ini. Setelah penonton melihat film "Booking Out", mereka dapat menyimpulkan, apakah film ini berada dalam kategori film fiksi ataupun film dokumenter.

\section{DAFTAR PUSTAKA}

Atmasasmita, Romi. 1995. Kapita Selekta Hukum Pidana dan Kriminologi. Bandung: Mandar Maju.

Bordwell, David. 2008. Film Art: an Introduction. New York: Mcgraw Hill

Dancyger, Ken. 2006. The Director's Idea: The Path to Great Directing. USA: CRC Press.

Hight, Craight. 2016. Television Mockumentary: Reflexifity, Satire, And A Call To Play. Manchester: Manchester University Press. 


\section{Luluk Ulhasanah}

Pemaknaan Stereotip Gender Dan Kelas Sosial Pada Film Little Women

Hight, Craigt, dan Roscoe. 2001. Faking It:

Mock-documentary and the Subversion of Factuality.

Manchester: Manchester University Press.

Livingstone, Don.1984. Film and The Director. Terjemahan Masfil Nurdin.

Mascelli, Joseph V. 2010. The Five C's Cinematography. Los Angeles:SilmanJames Press.

Nichols, Bill. 2001. Introduction to Documentary. USA:Indiana University Press.
Pratista, Himawan. 2008. Memahami Film. Yogyakarta: Montase Press.

Rabiger, Michael. 2003. Directing Film Techniques and Aesthetics. USA: Focal Press

Silverman. 1993. Questioning Foundation: Truth / subjectivity/ cultur. USA: Routledge.

Ward, Peter. 2003. Picture Composition for Film and Television. Milton Park: Taylor \& Francis.

Wibowo, Fred. 1997. Dasar-dasar produksi televisi. Indonesia: PT. Grasindo. 